\title{
The epiphytic orchids lonopsis utricularioides and Psygmorchis pusilla associate with different Ceratobasidium lineages at Valle del Cauca, Colombia
}

Rafael Borges da Silva Valadares ${ }^{1,2}$, Joel Tupac Otero ${ }^{3}$, Marlon Corrêa Pereira ${ }^{4}$, and Elke Jurandy Bran Nogueira Cardoso

Received: October 25, 2013. Accepted: September 1, 2014

\begin{abstract}
In Orchidaceae, association with symbiotic fungi is required for seed germination and seedling development, thereby being the main energy source during the first steps of germination. Colombia is one of the countries with the greatest biodiversity of orchids, with an estimated 3,200 species, but few studies on orchid mycorrhiza have been conducted. In our study, we isolated and sequenced the internal transcribed spacer rDNA region of fungi from two co-occurring Colombian epiphytic orchids, I. utricularioides and P. pusilla, both belonging to the subtribe Oncidiinae. All sequences were recognized as belonging to the genus Ceratobasidium, known to be a common orchid mycorrhizal fungus in both tropical and temperate orchids. One sequence was $100 \%$ similar to fungi isolated from I. utricularioides in Costa Rica in a previous study. I. utricularioides was confirmed to be a specialist, associating with only one clade of mycorrhizal fungi. However, $P$. pusilla was shown to be a generalist, associating with three clades. This finding indicates that the variation in mycorrhizal specificity could be an important factor in the co-existence of orchids. The high affinity between the subtribe Oncidiinae and Ceratobasidium was also reinforced.
\end{abstract}

Keywords: Co-existence, ITS phylogeny, Mycorrhiza, Orchidaceae, Specificity

\section{Introduction}

Orchidaceae represents the largest flowering plant family with more than 27,135 accepted species (The Plant List 2010), which represents roughly $10 \%$ of the diversity of the plant kingdom. Colombia has an estimated 3,500 orchid species (Dodson 2003), representing $>15 \%$ of global orchid species (Senghas 2001; Ortiz et al. 1994; Dressler 1993; Arditti 1992). However, this number may well be considerably underestimated due to the lack of studies on this subject in the past 30 years (Dodson 2003).

Regardless of their carbon nutrition during the adult stage, all orchids produce endosperm-lacking seeds and are dependent on orchid mycorrhizal (OM) fungi for germination and establishment of seedlings (Dearnaleyet al.2012). The dependence on OM fungi may be conserved throughout the life-cycle of some orchids, while others may receive carbon by either $\mathrm{CO}_{2}$ fixation or mycorrhizal transfer after establishing photosynthesis (Rasmussen \&
Rasmussen 2009). Thus, the availability of suitable mycorrhizal fungi able to germinate or to symbiotically associate with adult orchids is probably a key factor constraining the distribution of orchid species (Otero et al. 2007).

Most orchid mycorrhizal fungi belong to the genus Rhizoctonia, a diverse polyphyletic group of pathogens, endophytes, saprophytes, and mycorrhizal fungi (Roberts 1999; Bayman \& Otero 2006). This group includes the anamorphic (asexual) genera Ceratorhiza, Epulorhiza, Moniliopsis, and Rhizoctonia (Moore 1987) of a variety of teleomorphs (sexual stages) of Ceratobasidium, Sebacina, Thanatephorus, and Tulasnella (Roberts 1999). Because these fungi rarely produce sexual spores under culture conditions, this group has always posed a difficulty for taxonomists. The diversity of Rhizoctonia-forming fungi has usually been described with molecular methods, such as sequencing of the internal transcribed spacer (ITS) that is highly variable among groups (Otero et al. 2002; 2004; Sharon et al. 2008). This region is considered the universal

\footnotetext{
${ }^{1}$ Departamento de Ciências do Solo, Escola Superior de Agricultura “Luiz de Queiroz", Universidade de São Paulo. Avenida Pádua Dias 11, Piracicaba, São Paulo, Brazil. CEP 13417-290.

${ }^{2}$ Instituto Tecnológico Vale Desenvolvimento Sustentável. Rua Boaventura da Silva 955. CEP 66050-000. Belém-PA.

${ }^{3}$ Departamento de Ciencias Biológicas, Instituto de Estudios Ambientales, Universidad Nacional de Colombia sede Palmira, UNAL-Palmira, Colombia. Cra 32 No. 12-00, Palmira, Valle del Cauca, Colombia.

${ }^{4}$ Instituto de Ciências Biológicas e da Saúde, Universidade Federal de Viçosa - Campus de Rio Paranaíba, Rodovia MG-230 Km 7, Rio Paranaíba - MG, Caixa Postal 22, Brazil. CEP: 38810-000.

Corresponding author email: marloncp@gmail.com
} 
barcode for fungal identification (Schochet al. 2012) and several oligonucleotides have been developed to address orchid mycorrhizal diversity (Taylor \& McCormick 2008).

Recent studies have researched tropical orchids in South and Central America (Otero et al. 2002; 2004; 2005; Pereira et al. 2005; Otero et al. 2007; Otero \& Bayman 2009; Pereira et al. 2009; Valadares et al. 2012; Oliveira et al. 2014; Pereira et al. 2014), but only one demonstrated ITS rDNA sequences from mycorrhizal fungi in Colombia (Mosquera et al. 2010; 2013). In Ecuador, Suarez et al. (2006) isolated mycorrhizal fungi belonging to the genera Tulasnella and Sebacina. In Brazil, many clades of Tulasnella (Epulorhiza) have been found in several species (Pereira et al. 2005; 2009; Pereira \& Valadares 2012; Nogueira et al. 2014; Pereira et al. 2014) and Ceratobasidium has also been detected in a recent study of Coppensia doniana (sin. Oncidium donianum) (Valadares et al. 2012). When studying Ionopsis utricularioides and Tolumnia variegata in Puerto Rico, both epiphytic orchids belonging to the subtribe Oncidiinae, using both phylogeny studies and symbiotic germination assays, Otero et al. (2002; 2004) demonstrated variation in the mycorrhizal specificity between these plants and high preference of this subtribe for the genus Ceratobasidium. I. utricularioides showed more specialist association, while T. variegata was shown to be a less specific orchid, associating with different fungal clades.

As I. utricularioides in the Caribbean associate with specific mycorrhizal fungi, we expected I. utricularioides in our study to be specific to the same fungal clade. Moreover, we expected variation in the levels of mycorrhizal specificity between both studied species from Colombia, as occurred in the Caribbean. Therefore, we isolated and identified mycorrhizal fungi associated with two co-occurring Colombian epiphytic orchids, Psygmorchis pusilla and I. utricularioides, through molecular sequencing of the ITS ribosomal DNA, to investigated their degrees of mycorrhizal preferences and specificity.

\section{Material and Methods}

\section{Sampling}

Five individuals of I. utricularioides (Sw). Lindland and P. pusilla (L.) Dodson \& Dressler were selected for this study. Sampling was carried out near Sabaletas River near the city of Buenaventura $\left(3^{\circ} 25^{\prime} 00^{\prime \prime} \mathrm{N}, 77^{\circ} 03^{\prime} 11^{\prime \prime} \mathrm{W}\right)$, department of Valle del Cauca, along the Colombian Pacific coast. Plants were epiphytes on guava trees (Psidium guajava Linn.) and ornamental plants (such as Hybiscus rosa-sinensis Linn.). Young and healthy roots representing a part of the active root system were extracted with scissors and placed in paper bags. Samples were taken to the soil microbiology laboratory of the "Universidad Nacional de Colombia" in Palmira and were processed in less than one week.

\section{Isolation}

Isolation was carried out following Otero et al. (2002). Roots were washed in distilled water and cut into $3 \mathrm{~cm}$ segments. These fragments were superficially disinfected by washing in $70 \%$ ethanol for $1 \mathrm{~min}$ and $4 \mathrm{~min}$ in $20 \%$ sodium hypochlorite solution ( $0.5 \%$ active chlorine), followed by five washings with sterilized water. Fragments were then placed in potato dextrose agar (PDA) medium with $1 \mathrm{mg} / \mathrm{L}$ of streptomycin powder. After three days of incubation, plates were observed under light microscopy with 400x amplification. Fungal cultures with 'rhizoctonia' characteristics were cultivated in PDA plates and PD (potato dextrose broth) for further DNA extraction.

\section{ITS rDNA sequencing}

DNA was extracted from cultured fungi using the Invisorb DNA plant mini kit following the instructions of the manufacturer. Oligonucleotide primers ITS1 (5'TCCGTAGGTGAACCTGCGG) and ITS4 (5'TCCTCCGCTTATTGATATGC) were used to amplify the ITS region of genomic DNA as described by White et al. (1990). The reactions were performed in a MJ PTC-100 thermocycler and consisted of initial denaturing at $96^{\circ} \mathrm{C}$ for $1 \mathrm{~min}$, followed by 35 cycles of denaturing at $96^{\circ} \mathrm{C}$ for $1 \mathrm{~min}$, annealing at $52{ }^{\circ} \mathrm{C}$ for $30 \mathrm{~s}$, and extension at $72^{\circ} \mathrm{C}$ for $2 \mathrm{~min}$. The PCR product was purified using a QIAQuick $^{\circledR}$ purification kit prior to sequencing.

PCR products were sequenced in both directions using the ET dyenamic kit with the ABI 3100 sequencer. A reaction was labeled using $2.0 \mu \mathrm{L}$ of PCR product (60 $\mathrm{ng}$ of DNA), $2.0 \mu \mathrm{L}$ of ETdye mix, $2.0 \mu \mathrm{L}$ of "save money" buffer (200 mMTris-HCl, $\mathrm{pH} 9.0 ; 5 \mathrm{mM} \mathrm{MgCl}), 2.0 \mu \mathrm{L}$ of the primer ITS1 or ITS4 $(5 \mathrm{pmol} / \mu \mathrm{L})$, and $2 \mu \mathrm{L}$ of Mili-Q water. PCR was then processed setting the annealing temperature to $50{ }^{\circ} \mathrm{C}$.

\section{Fungal Identification and phylogenetic analysis}

A Blast search (www.ncbi.nlm.nih.gov/BLAST) was conducted using the BlastN (Altschul et al. 1990) algorithm on all the sequences to determine their closest known relatives and to confirm the ITS region of the nuclear rDNA was sequenced. Multiple sequences alignment was conducted with ClustalW and checked visually. The alignment parameters, gap opening, and gap extension penalties were both set from 0.1 to 10 . All positions containing gaps and deletion data were eliminated from the dataset (complete deletion option). The evolutionary history was inferred using the minimum evolution method. The evolutionary distances were computed using the Kimura-2-parameter method. The minimum evolution tree was searched using the close-neighbor-interchange algorithm at a search level of 0 . The neighbor-joining algorithm was used to generate the initial tree. The analysis involved 26 nucleotide sequences. 
All positions containing gaps and missing data were eliminated. Evolutionary analyses were conducted in MEGA 5 (Tamura et al. 2011).

\section{Results and discussion}

We collected five individuals of the epiphytic orchids I. utricularioides and P. pusilla in the Valle del Cauca state, Colombia. We obtained 13 isolates from I. utricularioides and nine isolates from $P$. pusilla. Sequencing was successful in both directions and produced contigs with 540 to 667 base pairs. All the sequences showed high similarity (>97\%) to the teleomorphic genus Ceratobasidium. The sequences from I. utricularioides belonged to one single clade, whereas sequences from P. pusilla grouped into three clades (Fig. 1).
Some sequences obtained from I. utricularioides were 99 to $100 \%$ related to Ceratobasidium JTO232 (Genebank accession number DQ084013.1), also isolated from I. utricularioides in a previous study in Costa Rica (Otero et al. 2007).

Ceratobasidium is one of the most common endophytes in temperate orchids and it has been vastly described in tropical orchids (Otero et al. 2002; Pereira et al. 2005; Otero et al. 2007; Valadares et al. 2012). Species of Ceratobasidium are characterized by the presence of a non-sporulating anamorphic phase and binucleate or uninucleate hyphae (Roberts 1999; Oberwinkler et al. 2013). From an ecological point of view, this genus includes saprophytic, symbiotic, and even parasitic lineages (Roberts 1999; Oberwinkler et al. 2013).

The distribution and diversity of orchid species may largely depend on the specificity of their orchid mycorrhizal interactions and also on the distribution of the orchid

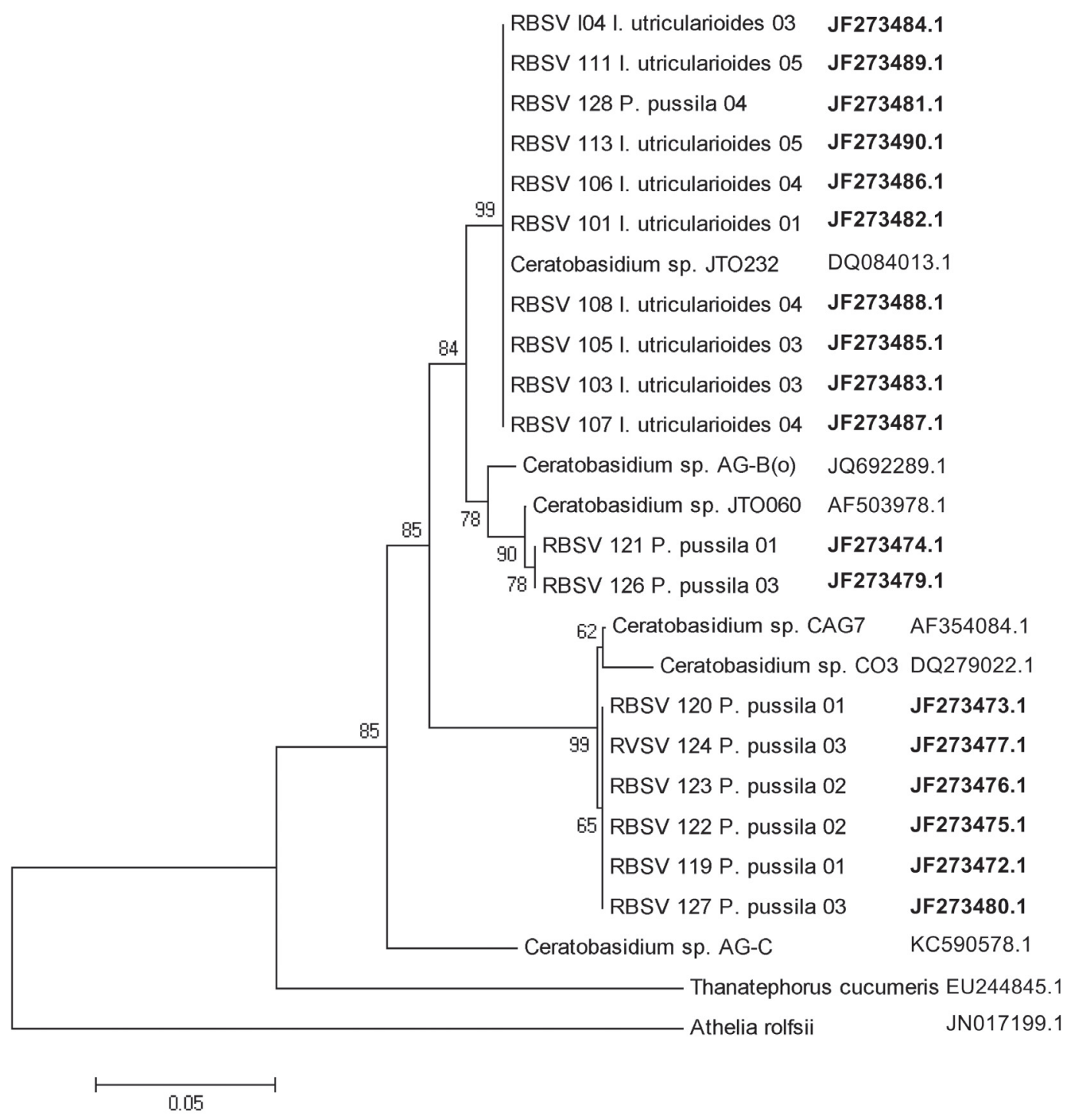

Figure 1: Phylogenetic tree of 19 isolates from the epiphytic orchids Ionopsis utricularioides and Psygmorchis pusilla isolated from Buenaventura, Valle del Cauca, Colombia. The tree is drawn to scale, with branch lengths in the same units as those of the evolutionary distances used to infer the phylogenetic tree. The evolutionary distances were computed using the maximum composite likelihood method (Tamura et al.2011) and are in the units of the number of base substitutions per site. 
mycorrhizal fungi. An understanding of these obligate associations is of crucial importance for orchid ecology and conservation (Otero \& Flanangan 2006).

A species is specific for a given interaction if it interacts with a limited number of partner species (Thompson 1994). It is useful to discuss specificity in a relative way comparing related species. In this sense, the concept "degrees of specificity" should be kept in mind. Thus, a species can be more or less specific than others in an ecologically comparable situation. However, specificity is less expected in ecological interactions because those individuals that are able to interact with many partners should have more choices than those that interact with a narrow range of partners (Timms \& Read 1999; Otero et al. 2002).

Our results showed that while both epiphytic orchids belong to the same subtribe (Oncidiinae), they vary in mycorrhizal preferences. Fungal phylogeny showed that in Colombia, as in other regions, I. utricularioides is more specific than other orchids from the same subtribe in its mycorrhizal relationships. The fact that I. utricularioides was found to be associated with only one mycorrhizal clade corroborates the previous work of Otero et al. with the same species (2002; 2005 ; 2007). On the other hand, our data pointed to a less specific behavior of $P$. pusilla, as this species is associated with multiple Ceratobasidum lineages. Indeed, the specificity degree of P. pusilla is comparable to that observed in the other epiphytic tropical Oncidiinae, T. variegata and C. doniana in studies conducted in Puerto Rico (Oteroet al. 2002) and in Brazil (Valadares et al. 2012), respectively.

The high specificity shown by I. utricularioides may not be due to limited availability of suitable partners (Perkins \& McGee 1995). Its co-occurring orchid, P. pusilla was associated to three different clades of fungi from the same genus, suggesting that Ceratobasidium lineages are widespread at that site. Moreover, sequence similarity of fungi isolated from I. utricularioides with a sequence from Costa Rica (JTO232) shows that the association of I. utricularioides with this specific fungal lineages is a common phenomenon in the investigated regions.

High mycorrhizal specificity suggests that fungi could play a role in orchid speciation and diversification (Rasmussen 1995; Taylor et al. 2002). Here, we have identified two mycorrhizal specificity patterns: 1) I. utricularioides associates with only one widespread fungal clade and 2) P. pusilla accociates with three fungal clades. On the other hand, all symbionts isolated from orchids belonging to the Oncidiinae sub-tribe, up to the present day, fall in the genus Ceratobasidium.

Co-occurring orchid species tend to use different fungal partners, consistent with their expected role in reducing competition for nutrients (Waterman et al. 2011). Although without a broader sampling approach it is difficult to verify, we hypothesize that these two orchid species use different fungal partners as a strategy to succeed in the same environment. Therefore, the variation in levels of specificity and fungal preferences may be important to explain orchid coexistence.

\section{Conclusions}

The two epiphytic orchids belonging to the subtribe Oncidiinae showed different mycorrhization strategies. I. utricularioides associated with one clade of a widespread fungus of the genus Ceratobasidium. However, P. pusilla was shown to be more generalist by associating with three different clades of the same genus. The high affinity between the subtribe Oncidiinae and the genus Ceratobasidium was also reinforced. Our study highlights the significance of studying orchid mycorrhizal specificity and diversity for better understanding of orchid distribution.

\section{Acknowledgments}

To Fundação de Amparo à Pesquisa de São Paulo (FAPESP) for providing funding for this research. RBSV acknowledges a mastership grant from CAPES, which was given by Programa de Pós-graduação em Microbiologia Agrícola, ESALQ/USP. To Francisco Molineros that provided assistance in plant sampling and to the Orchid research group (COL0066015) that logistically supported the project.

\section{References}

Altschul SF, Gish W, Miller W, Myers EW, Lipman DJ. 1990. Basic local alignment search tool. Journal of Molecular Biology 215:403-410.

Arditti J. 1992. Fundamentals of orchid biology. New York, John Wiley \& Sons.

Bayman P, Otero JT. 2006. Microbial endophytes of orchid roots: diversity and effects on plants. In: Schulz B, Boyle C, Sieber T. (eds). Microbial Root Endophytes.Soil Biology 9. Berlin, Springer-Verlag, Berlin Heidelberg. p 153-178.

Dearnaley JDW, Martos F, Selosse MA. 2012. Orchid Mycorrhizas: Molecular Ecology, Physiology, Evolution and Conservation Aspects. In: Esser K, Hock B. (eds.) The mycota. Vol IX. 2nd edition. Berlin-Heidelberg, Springer-Verlag. p 207-230

Dodson CH. 2003. Why are there so many orchid species? Lankesteriana 7: 99-103.

Dressler RL. 1993. Phylogeny and classification of the orchid family. London, Cambridge University Press.

Moore RT. 1987. The genera of Rhizoctonia-like fungi: Ascorhizoctonia, Ceratorhizagen. nov., Epulorhiza gen. nov., Moniliopsis, and Rhizoctonia.Mycotaxon 29: 91-99.

Mosquera-Espinosa AT, Bayman P, Otero JT. 2010. Ceratobasidium como hongo micorrízico de orquídeas em Colombia. Acta Agronómica 59: 316-326

Mosquera-Espinosa AT, Bayman P, Prado GA, Gomez-Carabali A, Otero JT. 2013. Pathogenicity of orchid mycorrhizal fungi (Ceratobasidium sp.) on rice and biocontrol of Rhizoctonia solani sheath blight. Mycologia 105: 141-150.

Nogueira RE, Berg CVD, Pereira OL, Kasuya MCM. 2014. Isolation and molecular characterization of Rhizoctonia-like fungi associated with orchid roots in the Quadrilátero Ferrífero and Zona da Mata regions of the state of Minas Gerais, Brazil. Acta Botanica Brasilica 28: 298-300.

Oberwinkler F, Riess K, Bauer R, Kirschner R, Garnica S. 2013. Taxonomic re-evaluation of the Ceratobasidium-Rhizoctonia complex and Rhizoctonia butinii, a new species attacking spruce. Mycological Progress 12: 763-776.

Oliveira SF, Bocayuva MF, Veloso TGR, et al. 2014. Endophytic and mycorrhizal fungi associated with roots of endangered native orchids from the Atlantic Forest, Brazil. Mycorrhiza 24: 55-64. 
Ortiz P, Aguirre G, Arango A, Arango C, Bock I. 1994. Native Colombian Orchids. Sociedad Colombiana de Orquideología. Vol. 1. Medellín, Editorial Colina.

Otero JT, Ackerman JD, Bayman P. 2002. Diversity and host specificity of endophytic Rhizoctonia-like fungi from tropical orchids. American Journal of Botany 89: 1852-1858.

Otero JT, Ackerman JD, Bayman P. 2004. Differences in mycorrhizal preferences between two tropical orchids. Molecular Ecology 13: 2393-2404.

Otero JT, Bayman P, Ackerman JD. 2005. Variation im mycorrhizal performace en the epiphytic orchid Tolumnia variegata in vitro: the potential for natural selection. Evolutionary Ecology 19: 29-43.

Otero JT, Flanagan NS. 2006. Orchid diversity - beyond deception. Trends in Ecology \& Evolution 21: 64-65.

Otero JT, Flanangan NS, Herren EA, Ackerman JD, Bayman P. 2007. Widespread mycorrhizal specificity correlates do mycorrhizal function in the neotropical epiphytic orchid Ionopsis utricularioides (Orchidaceae). American Journal of Botany 94: 1944-1950.

Otero JT, Bayman P. 2009. Germinación simbiótica y asimbiótica en semillas de orquídeas epífitas. Acta Agronómica 58: 270-276.

Pereira MC, Pereira OL, Costa MD, Rocha RB, Kasuya MCM. 2009. Diversity of mycorrhizal fungi Epulorhiza spp. isolated from Epidendrum secundum (Orchidaceae). Revista Brasileira de Ciências do Solo 33: 1187-1197.

Pereira MC, Valadares RBS. 2012. Diversidade e aplicação dos fungos micorrízicos de orquídeas brasileiras. In: Pazza R, Souza EA, Pereira JD, Kavalco KF, Lisboa LCO, Reis LB, Pereira MC. (eds.) Biodiversidade em foco. Rio Paranaíba, Araucária Comunicação Integrada.

Pereira MC, Coelho, IS, Valadares RBS, et al. 2014. Morphological and molecular characterization of Tulasnella spp. fungi isolated from the roots of Epidendrum secundum, a widespread Brazilian orchid. Symbiosis 62: 111-121.

Pereira OL, Kasuya MCM, Borges AC, Araújo EF. 2005. Morphological and molecular characterization of mycorrhizal fungi isolated from neotropical orchids in Brazil. Canadian Journal of Botany 83: 54-65.

Perkins AJ, McGee PA. 1995. Distribution of the orchid mycorrhizal fungus, Rhizoctonia solani, in relation to its host, Pterostylis acuminata, in the field. Australian Journal of Botany 43: 565-575.

Rasmussen HN. 1995. Terrestrial orchids: from seed to mycotrophic plant. Cambridge, Cambridge University Press.

Rasmussen HN, Rasmussen FN. 2009. Orchid mycorrhiza: implications of a mycophagous life style. Oikos 118: 334-345
Roberts P. 1999. Rhizoctonia-forming fungi. Kew, Whitstable Litho Printers. Schoch CL, Seifert KA, Huhndorf S, et al. 2012. Nuclear ribosomal internal transcribed spacer (ITS) region as a universal DNA barcode marker for Fungi. Proceedings of the National Academy of Sciences 109: 6241-6246.

Senghas K. 2001. Die orchideen. Vol. I/C, fasc. 44/45. 3rd edn. Berlin, Parey Buchver-Lag.

Sharon M, KuninagaS,Hyakumachi M. 2008. Classification of Rhizoctonia spp. using rDNA-ITS sequence analysis supports the genetic basis of the classical anastomosis grouping. Mycoscience 49: 93-114.

Suarez JP, Weiß M, Abele A, Garnica S, Oberwinkler F,Kottke I. 2006. Diverse tulasnelloid fungi form mycorrhizas with epiphytic orchids in an Andean cloud forest. Mycological Research 110: 1257-1270.

Tamura K, Peterson D, Peterson N, Stecher G, Nei M, Kumar S. 2011. MEGA 5: Molecular Evolutionary Genetics Analysis using Maximum Likelihood, Evolutionary Distance, and Maximum Parsimony Methods. Molecular Biology and Evolution 28: 2731-2739.

Taylor DL, Bruns TD, Leake JR, Read DJ. 2002. Mycorrhizal specificity and function in myco-heterotrophic plants. In: Heijden MGAVD, Sanders I. (eds.) Mycorrhizal Ecology. Berlin, Springer-Verlag. p. 375-414.

Taylor DL, McCormick MK. 2008. Internal transcribed spacer primers and sequences for improved characterization of basidiomycetous orchid mycorrhizas. New Phytologist 177: 1020-1033.

The Plant List 2010.The Plant List. Version 1. http://www.theplantlist.org/.

Thompson JN. 1994. The coevolutionary Process. Chicago, University of Chicago Press.

Timms R, Read AF. 1999. What makes a specialist special? Trends in Ecology and Evolution 14: 333-334.

Valadares RBS, Pereira MC, Otero JT, Cardoso EJBN. 2012. Narrow mycorrhizal diversity in a population of the orchid Coppensiadoniana. Biotropica 44: 114-122.

Waterman RJ, Bidartondo MI, Stofberg J, et al. 2011. The Effects of Aboveand Below ground Mutualisms on Orchid Speciation and Coexistence. The American Naturalist 177: 54-68.

White TJ, Bruns TD, Lee S, Taylor J. 1990. Amplification and direct sequencing of fungal ribosomal RNA genes for phylogenetics. In: Innis MA, Gelfand DH, Sninsky JJ, White TJ. (eds.) PCR Protocols: a guide to methods and applications. San Diego, Academic Press. p. 315-322. 